\title{
Effects of low doses of chlormadinone acetate in the rat
}

\author{
M. M. Sharma, G. Lal and D. Jacob \\ Reproduction Physiology Section, \\ Department of Zoology, University of Rajasthan, \\ Jaipur 301004, India
}

Chlormadinone acetate (6-chloro-6,17 $\alpha$-acetoxyprogesterone) is a synthetic highly potent progestagen with antiandrogenic properties (Kincl, Maqueo \& Dorfman, 1965). Treatment with chlormadinone acetate causes inhibition of spermatogenesis in the rabbit (Ericsson, Dutt \& Archdeacon, 1964), and in the rat in which the effect was reversible (Dörner, Gotz \& Mainz, 1972). Dörner et al. (1972) used a dose of $10 \mathrm{mg}$ chlormadinone acetate/day, but in the present study lower doses were investigated.

The animals used were 4 to $4 \cdot 5$-month-old adult males (300-325 $\mathrm{g}$ body wt) of proven fertility from the departmental colony of Wistar albino rats. The control and 3 experimental groups each contained 6 animals which were housed individually. Animals in the experimental groups received a daily i.m. injection of $0.2,0.5$ or $1.0 \mathrm{mg}$ chlormadinone acetate in $0.1 \mathrm{ml}$ olive oil for 40 days. The control rats were similarly treated but with the olive oil vehicle alone. The animals were killed $24 \mathrm{hr}$ after the last injection; the reproductive organs and the pituitary glands were dissected out, cleared from adherent tissue and weighed to the nearest $\mathrm{mg}$ on a torsion balance. For histological observations representative testicular tissues were fixed in Bouin's fluid, sectioned and stained in Harris' haematoxylin and eosin. The amount of cholesterol in the testis and of fructose in the coagulating gland was determined by the method of Hawk, Oser \& Summerson (1954) and Mann (1964), respectively. The pituitary gonadotrophin potency of the rats was evaluated by the immature mouse uterine weight assay (Burrows, 1939). In this bioassay 21-day-old female Swiss albino mice from the departmental colony were used.

The results are given in Table 1 . With increasing doses of chlormadinone acetate there was a corresponding decline in the weights of the testis, accessory sex organs and pituitary. Pituitary gonadotrophin potency and fructose content of the coagulating gland decreased, whilst testicular cholesterol levels increased. The values for the rats treated with $0.2 \mathrm{mg}$ chlormadinone acetate/day were not significantly different from those for the control rats. Spermatogenesis also appeared normal in the testicular sections of these rats. In the other two experimental groups spermatogenesis had ceased and there were no spermatozoa in smears of the epididymal contents expressed from cuts in the cauda epididymides. Spermatozoa were present in the epididymides of the rats treated with the lowest dose of chlormadinone but they were not motile when examined in saline at room temperature, suggesting a selective antiandrogenic effect of chlormadinone acetate on this androgen-sensitive target structure.

The present results in the rat lead to the conclusion that chlormadinone acetate, like cyproterone acetate (Prasad, Singh \& Rajalakshmi, 1970), is capable of selectively impairing epididymal function and maturation of spermatozoa at low doses without affecting appreciably either the pituitary gonadotrophin secretion or testicular function.

This investigation was supported by grants from the University Grants Commission and the Indian Council of Medical Research, to whom two of us (M.M.S. and G.L.) are indebted for Junior Research Fellowships. We thank Professor A. S. Kapoor and Dr R. S. Mathur for departmental facilities.

\section{References}

Burrows, H. (1939) The effect of progesterone on the gonadotrophic potency of the rat. $J$. Endocr. 1, 417419.
DöRner, G., GOTZ, F. \& MAINZ, K. (1972) Infertility and maintained sexual behaviour in male rats treated with chlormadinone acetate. $J$. Endocr. 52, 197-198. 
M. M. Sharma et al.

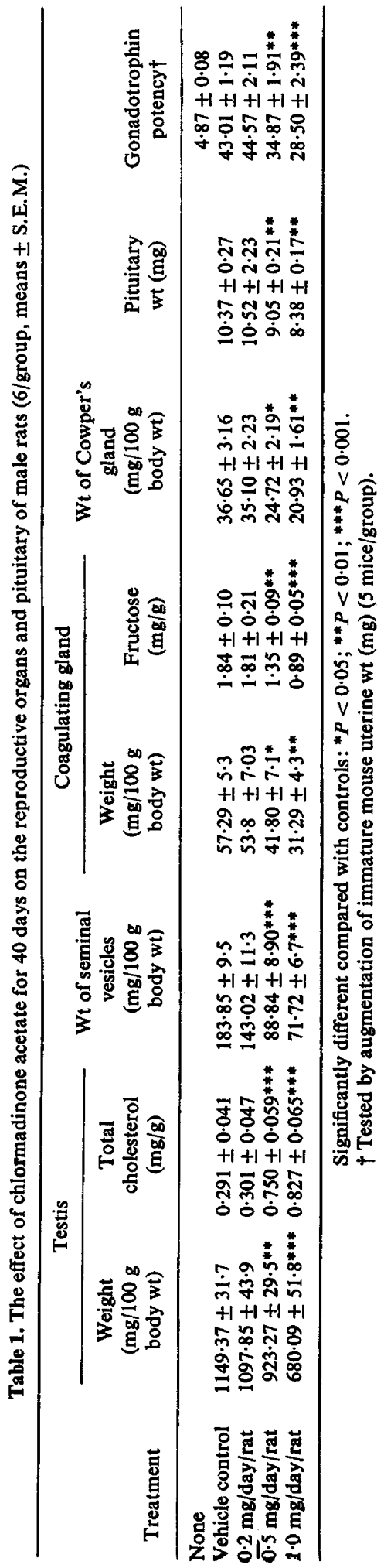


Ericsson, R.J., Dutt, R.H. \& Archdeacon, J.W. (1964) Progesterone and 6-chloro- $\Delta^{6}, 17$-acetoxyprogesterone as inhibitors of spermatogenesis in the rabbit. Nature, Lond. 204, 261-263.

HAWK, P.B., OSER, B.L. \& SummerSON, W.H. (1954) Practical Physiological Chemistry. McGraw-Hill, New York.

Kincl, F.A., MaQueo, M. \& Dorfman, R.I. (1965) Influence of various steroids on testes and accessory sex organs in the rat. Acta endocr., Copenh. 49, 145154.

MANN, T. (1964) The Biochemistry of Semen and of the Male Reproductive Tract. Methuen, London.

Prasad, M.R.N., Singh, S.P. \& Rajalakshmi, M. (1970) Fertility control in male rats by continuous release of microquantities of cyproterone acetate from subcutaneous Silastic capsules. Contraception 2, 165-178.

Received 12 February 1976 